UDC 378.1

\title{
MOTIVATION AND STIMULATION OF EFFECTIVE TEACHING AND LEARNING PROCESS
}

\author{
I. V. Boiko \\ Kyiv, National technical university of Ukraine \\ "Kyiv polytechnic institute" \\ irina-boiko@ukr.net
}

This article deals with the methods of motivation and stimulation of successful teaching and learning process in higher education, their role in the education system and the impact on the educational process itself, as well as the full development of student's personality. The basic methods of encouragement and disciplinary actions of students in learning, their theoretical justification and features of the practical application of science teaching were investigated. The article presents a classification of the main motives for learning and personal development of students in the higher education. It also examines the main types of pedagogic assessment, namely substantive and personal, material and moral, and effective procedural, quantitative and qualitative types of pedagogic assessment. Along with the types of educational assessments, the ways to stimulate learning and educational success are determined, chief among them: attention, approval, recognition, assessment, and support, reward, increasing social role, prestige and status of the student as a person. Each of these methods of stimulation is considered separately. The article highlights the methods of stimulation and motivation, which are divided into two main groups, namely methods of formation of cognitive interests and methods of formation of the sense of duty and responsibility in education. Methods of formation of cognitive interest include: creating a situation in class curiosity - an introduction to the learning process of certain interesting examples of experiments and paradoxical facts, usage of interesting analogies, creating a situation of novelty, relevance, making up game situations in the classroom, educational discussion, stimulation with analysis of life situations, creating success in learning situations. Methods aimed at creating a sense of duty and responsibility in education include the nomination of educational requirements and encouragement of learning and condemnation.

Key words: methods of stimulation in teaching and learning process, motivation, motives for knowledge, encouragement and disciplinary actions, the teaching and learning process, pedagogic assessment, approval and recognition.

Introduction. In modern teaching and learning process there are numerous difficult problems but among the key ones stands the problem of stimulation which presupposes the ways how to influence the students with the purpose to obtain the desired discipline and responsible behavior. For this aim it is necessary to consider the fact that in the teaching and learning process we pay due consideration to the discipline based not on fear that redeems students from self-confidence and generates dishonesty, but the discipline based on high consciousness and responsibility. In particular sense, this is the core of main difficulties, research and pedagogic work as the success of teaching and learning process depends on effective stimulation.

The problem of application of the methods of encouragement and disciplinary actions has been studied by various teachers and scientists, in particular K.D. Ushinskiy, L.M. Tolstoy, V.A. Sukhomlynskiy, A.S. Makarenko, nowadays L.Yu. Gordin, N.Ye, Shchurkova, V.Yu. Pytiukov, E.I. Kyrychuk, L.P. Kychatinova, A.I. Lipkina, A.K. Markova, T.A. Matis, A.B. Orlova and others are studying this problem. But it is obvious that these and other scientists are full of contradictory assertions with very 
generalized definitions of encouragement an punishment and the attempts to reveal them as "universal" educational methods to their full pedagogic meaning denial.

The reason of such a state is that in pedagogic science there is no accurate understanding and definition of the essence of encouragement and punishment as the teaching methods. As a result, some contradictory approaches in the theory have negative impact on these methods use in practice.

Thus, thematic justification of this article is to validate its aim - to consider the stimulation and motivation methods of encouragement and punishment and their application in practical teaching and learning process.

The encouragement method occupies the special place in the teaching and learning process in higher educational institutions. Encouragement is the way of expressing positive assessment of studying, behavior and activity of the particular person of the group. It facilitates the surge of energy, good mood and readiness for further work, pleasure, gladness stipulated by public recognition of efforts and achievements [5, p. 64].

Motive is a stimulating reason for people's actions and behavior. However, motives do not originate on their own. Basically, motives have particular inner (primary or natural) and secondary (material or moral) reasons that do not find their expression explicitly in the majority of cases. The explicit expression of these reasons is the interest. Moreover, motives can appear under the outer reasons influence. Among these reasons, stimulants take important place. The motive is defined as the outer influence on the person or group that encourages them for purposeful action.

There is a certain classification of motives for effective teaching and learning process:

- Motive of perception (constant desire to receive new professional knowledge and skills),

- Motive of freedom (the need for independence, self-determination, personal views, actions and judgments),

- Motive of convenience (the desire to have good and positive relations in the group and surrounding),

- Motive of recognition (formation of personal status, image and prestige),

- Motive of risk reduction (the need to feel confidently and securely),

- Motive of benefit (the desire to achieve leading positions in studies rating),

- Motive of self-realization (the need to achieve personal goals, disclosure of personal skills and talents),

- Motive of participation (the desire to assist, provide help and be useful in solving some educational problems) [7, p. 252].

Stimulating methods. There is organic interconnection between different methods of teaching and learning process stimulating. Guided by the principal of optimality when choosing the particular methods it is required to have regard to the fact that every method is aimed at solving some identified sphere of pedagogic work and meanwhile it should be additionally oriented at solving secondary teaching problems. Here arises the necessity of possibility assessment of every method, the knowledge of its advantages and disadvantages and the choice of perfect combination of methods grounded on these requirements [6, p. 57].

The methods of encouragement and punishment have been applied in pedagogic practice for a long time. The main methods aim at some innovations 
creations in the teaching and learning process. They are used when we need to strengthen positive motivation or reduce negative incentives. We should bear in mind that encouragement and punishment influence all the personality of students and are deeply experienced by them. That is the reason why it is required to take into consideration the peculiar features of students' characters. Shy and lacking of confidence students especially need encouragement. Positive assessment of learning results, behavior and students' actions contribute to their moral and spiritual development as well. Encouragement aims at development. When the teacher distinguishes students' success, it contributes to their desire to learn and do more. That is why encouragement forms should be maximally dynamic and flexible. Encouragement rate stipulates the students to receive additional rights. It is necessary to bear in mind that it can lead to separate students' opposition to the rest of the group. That is why such encouragement should be applied with consideration of the group's public opinion and be the collective function. Meanwhile the teacher organizes teaching and learning process in such a way that will evoke the intention to be guided not by external stimulations but by high ideological and moral appeals [2, p.220].

Pedagogic assessment. The assessment itself is neither encouragement nor disciplinary action, it is the yardstick of knowledge, but almost every teacher is not able to avoid using it as a stimulation mean, so it should be done in the best possible way. The assessment is considered pedagogically effective when it creates the intention for self-development, gaining new knowledge and skills, development of positive personal traits and socially useful forms of cultural behavior [8, p. 160].

There are several kinds of pedagogic assessment that are divided into some determined types: subject and personal, material and moral, effective and procedural, quantitative and qualitative.

Subject assessment concerns the action done by the student, but not his or her personality. In this case, the content, subject, process and results of activity are under consideration, but not the subject itself.

Personal pedagogic assessments vice versa concern the subject of activity, but not its attributes, they identify personal features of students reflected in their activity, their endeavor, skills, perceptions etc. In this case, the students are stimulated for educational process and for personal development through the assessment of their activity, and in the case of subject assessments - through the evaluation of how they are studying.

Material pedagogic assessments include different variants of material stimulation of students for success in educational and morale building work.

Moral pedagogic assessment includes praise or condemnation the characteristics of students' activities from the point of view of their responsibility to general moral norms.

Effective assessments concern the result of activity; they concentrate attention on it, not taking into account other educational attributes. In this case, final achievements are assessed, but not the studying process itself.

Procedural pedagogic assessments vice versa concern the teaching and learning process itself, but not the result.

Quantitative assessments are associated with the progress or amount of work completed.

Qualitative assessments concern the quality of studies, accuracy, diligence, endeavor and the like criteria of outperform. 
Except for the mentioned pedagogic assessment types there are other stimulation ways as follows: attention, approval, recognition, evaluation, support, reward, social role, prestige and status boost [4, p. 320].

Beneficial attention has always been among the most effective forms of motivation. The teacher pays special attention to the student who shows sincere interest and using this method, the teacher stimulates the students for further educational achievements. Such attention is often accompanied by praise and encouragement that stipulates motivational function.

Approval is determined as positive assessment of the students' activities. Under such approval we understand positive evaluation of students' actions, behavior, responsibility and achievements. It can be verbal and non-verbal or often combined assessment.

Recognition means the assignment of certain benefits of the person under assessment and his high mark; it shows the particular criterion of evaluation.

Evaluation includes the classification of development rate of the particular skill and the assessment of activities and results [1, p. 65].

Support as a stimulation type appears in the way the teacher approves certain actions of the students, he stimulates him for their repetition and successful result. It is often employed in the cases when a student needs help from outside.

Under the term reward, we should understand the way of material support or assessment. It is a stimulus for further activity in case of valid estimate when it corresponds to effort expended and the result achieved [2, p. 153].

Classes of stimulation methods. The group of stimulation methods can be divided into two main classes. The first class includes the methods aimed at cognitive interest formation. The second class includes the methods aimed at the sense of responsibility formation within effective teaching and learning process. More details follow:

Cognitive interest formation methods presuppose:

1. Creation of interesting situations during the lesson - introduction of interesting modern examples, experiments, no intuitive paradoxical facts;

2. Application of interesting analogies;

3. Creation of novelty situations, actuality application during teaching and learning process;

4. Classroom discussions;

5. Stimulation with the help of real-life situations analysis;

6. Application of game situations during the lessons;

7. Making up successful situations in educational process, which is deemed to be among the most effective ways to stimulate interest between those students who have some difficulties with studies. It is known that without joy and gladness experience it is impossible to count on further success in the learning process. The teacher by means of encouragement and approval of students' efforts creates such situations. It is important to maintain favorable spiritual and psychological working environment reducing the feelings of fear, uncertainty and shyness. In this case, the anxiety state is replaced by self-confidence [9, p. 203].

Methods aimed at creating the sense of responsibility formation within effective teaching and learning process. The teaching and learning process is based not only on motives of cognitive interest, but on the other motives as well, among which the most important are the motives of duty and responsibility. They allow 
students to overcome difficulties in studies, to feel joy and gladness thanks to the success achieved. These motives form on the grounds of application of the following methods: putting forward demands, teaching to meet requirements, encouraging successful and diligent performance of duties, in-process monitoring of meeting educational requirements and when required pointing out the mistakes, disapproval aimed at responsible attitude formation [3, p. 421].

Conclusions. Consequently, the methods of motivation and stimulation of successful teaching and learning process in higher education, their role in the education system and the impact on the educational process itself, as well as the full development of the individual student have been considered in this article. The basic methods of encouragement and disciplinary actions in learning, their theoretical justification and features of the practical application of science teaching have been dealt with. The classification of the main motives for learning and personal development of students in the higher education has been provided. The main types of pedagogic assessment have been recognized. Along with the types of educational assessments, the ways to stimulate learning and educational success are determined.

\section{REFERENCES}

1. Ксензова Г. Ю. Инновационные технологии обучения и воспитания школьников: учеб. пособие / Г. Ю. Ксензова. - М.: Педагогическое общество России, 2008. - 128 с.

2. Макаренко А.С. Книга для родителей / А.С. Макаренко. - М.: Лениздат, 1981. - 319 с.

3. Максимюк С.П. Педагогіка: Навчальний посібник / С.П. Максимюк. К.: Кондор, 2005. - 667 с.

4. Масленкова Л.И. Теория и методика воспитания / Л.И. Масленкова, П. И. Пидкасистый. - М.: Педагогическое общество России. 2004. - 480 с.

5. Николаева Е.И. Кнут или пряник? Поощрение и наказание как методы воспитания ребенка / Е.И. Николаева. - СПб.: Речь, 2010. - 155 с.

6. Рожков М.И. Организация воспитательного процесса в школе: учеб. пособие для студ. высш. учеб. заведений / М.И. Рожков, Л.В. Байбородова. М.: Гуманит, изд. центр ВЛАДОС, 2000. - 256 с.

7. Сластенин В.А. Педагогика: учеб. пособие для студ. высш. пед. учеб. заведений / В. А. Сластенин, И. Ф. Исаев, Е. Н. Шиянов; Под ред. В.А. Сластенина - М.: Издательский центр «Академия», 2002. - 576 с.

8. Степанов Е.Н. Педагогу о современных подходах и концепциях воспитания / Е.Н. Степанов, Л.М. Лузина. - М.: ТЦ Сфера, 2008. - 244 с.

9. Щуркова Н.Е. Практикум по педагогической технологии / Н.Е. Щуркова. - М.: Педагогическое общество России, 1998. - 250 с.

\section{REFERENCES}

1. Ksenzova, Gh.Ju. (2008). Innovation technologies of pupils' education. Moscow. Russia: publishing center "Pedagogicheskoe obschestvo Rossii" [in Russian].

2. Makarenko, A.S. (1981). The book for parents. Moscow. Russia: "Lenizdat" [in Russian].

3. Maksymjuk, S.P. (2005). M17 Pedagogics. Teaching guide. Kyiv. Ukraine: Kondor [in Ukrainian].

4. Maslenkova, L.I. (2004). Theory and methodology of education, edited by Pidkasystyj, P.I. Moscow. Russia: publishing center "Pedagogicheskoe obschestvo Rossii" [in Russian].

5. Mykolajeva, Je.I. (2010). Carrot or stick? Encouragement and punishment as educational methods. St.Petersburg. Russia: Mova [in Russian]. 
6. Rozhkov, M.I., Bajborodova, L.V. (2000). Organization of educational process in school: teaching guide for students of higher pedagogic institutions. Moscow. Russia: humanitarian publishing center Vlados [in Russian].

7. Slastenin, V.A., Isajev, I.F., Shyjanov, Je.M. (2002). Pedagogics: teaching guide for students of higher pedagogic institutions. Edited by Slastenin, V.A. Moscow. Russia: Publishing center "Akademija" [in Russian].

8. Stepanov, O.M., Luzina, O.M. (2005). To the teacher about modern approaches and concepts of education. Moscow. Russia: TC Sfera [in Russian].

9. Shurkova, N.Je. (1981). Practicum on pedagogic technology. Moscow, Russia: publishing center "Pedagogicheskoe obschestvo Rossii" [in Russian].

\section{І. В. Бойко. Мотивація та стимулювання ефективного навчального процесу.}

У статті розглядаються методи мотивації та стимулювання успішного навчального процесу у вищій школі, їхня роль в системі освіти та вплив на сам освітній процес, а також на всебічний розвиток особистості студентів. Наведені основні методи заохочення та покарання студентів в процесі навчання, їхнє теоретичне обгрунтування та особливості застосування на практиці. У статті наведено класифікацію основних мотивів до навчання та особистісного розвитку студентів в процесі здобуття вищої освіти. Також розглядаються основні види педагогічної оцінки, а саме предметний та персональний, матеріальний та моральний, результативний та процесуальний, кількісний та якісний. Поряд 3 видами педагогічних оцінок виділяють способи стимулювання навчальних та виховних успіхів, головні: увага, схвалення, визнання, оцінка, підтримка, нагорода, підвищення соціальної ролі, престижу i статусу студента як особистості. Кожен 3 перелічених способів стимулювання розглядається окремо. Детально висвітлюються групи методів стимулювання та мотивації, що поділяються на дві основні підгрупи: методи формування пізнавальних інтересів та методи, спрямовані переважно на формування почуття обов'язку та відповідальності в навчанні. До методів формування пізнавального інтересу відносяться: створення на занятті ситуації зацікавлення - введення в навчальний процес цікавих прикладів, експериментів, парадоксальних фактів, використання цікавих аналогій, створення ситуації новизни, актуальності, моделювання в навчальному процесі ігрових ситуацій, навчальні дискусії, стимулювання за допомогою аналізу життєвих ситуацій, ситуації успіху в навчанні. Методи, спрямовані на формування почуття обов'язку та відповідальності в навчанні включають висунення навчальних вимог, а також заохочення та засудження в навчанні.

Ключові слова: методи стимулювання в навчанні, мотивація, мотиви до пізнання, заохочення та дисципліна, навчальний процес, педагогічна оцінка, схвалення, визнання.

\section{И. В. Бойко. Мотивация и стимулирование эффективного учебного процесса.}

В статье рассматриваются методы мотивации и стимулирования успешного учебного процесса в высшей школе, их роль в системе образования и влияние на сам образовательный процесс, а также на всестороннее развитие личности студентов. Приведены основные методы поощрения и наказания студентов в процессе обучения, их теоретическое обоснование и особенности применения на практике педагогической науки. В статье приведена классификация основных мотивов к обучению и личностного развития студентов в процессе получения высшего образования. Также рассматриваются основные виды педагогической оценки. Наряду с видами педагогических оценок выделяют способы стимулирования учебных и воспитательных успехов, главные из которых: внимание, одобрение, признание, оценка, поддержка, награда, повышение социальной роли, престижа и статуса студента как личности. Каждый из перечисленных способов стимулирования рассматривается отдельно. Подробно освещаются группы методов стимулирования и мотивации, которые делятся на две основные подгруппы: методы формирования познавательных интересов и методы, направленные преимущественно на формирование чувства долга и ответственности в учении.

Ключевые слова: методы стимулирования в обучении, мотивация, мотивы к познанию, поощрение и дисциплина, учебный процесс, педагогическая оценка, одобрение, признание. 